\title{
Speciation of Arsenic, Selenium, and Chromium in Wildfire Impacted Soils and Ashes
}

By Ruth E. Wolf, Todd M. Hoefen, Philip L. Hageman, Suzette A. Morman, and Geoffrey S. Plumlee

Open-File Report 2010-1242 


\section{U.S. Department of the Interior \\ KEN SALAZAR, Secretary}

\section{U.S. Geological Survey \\ Marcia K. McNutt, Director}

U.S. Geological Survey, Reston, Virginia 2010

For product and ordering information:

World Wide Web: http://www.usgs.gov/pubprod

Telephone: 1-888-ASK-USGS

For more information on the USGS-the Federal source for science about the Earth,

its natural and living resources, natural hazards, and the environment:

World Wide Web: http://www.usgs.gov

Telephone: 1-888-ASK-USGS

Suggested citation:

Wolf, Ruth E., Hoefen, Todd M., Hageman, Philip L., Morman, Suzette A., and Plumlee, Geoffrey S., 2010, Speciation of arsenic, selenium, and chromium in wildfire impacted soils and ashes: U.S. Geological Survey Open-File Report 2010-1242, $29 \mathrm{p}$.

Any use of trade, product, or firm names is for descriptive purposes only and does not imply endorsement by the U.S. Government.

Although this report is in the public domain, permission must be secured from the individual copyright owners to reproduce any copyrighted material contained within this report. 


\title{
Speciation of Arsenic, Selenium, and Chromium in Wildfire Impacted Soils and Ashes
}

\author{
By Ruth E. Wolf, Todd M. Hoefen, Philip L. Hageman, Suzette A. Morman, and Geoffrey S. Plumlee
}

\begin{abstract}
In 2007-09, California experienced several large wildfires that damaged large areas of forest and destroyed many homes and buildings. The U.S. Geological Survey collected samples from the Harris, Witch, Grass Valley, Ammo, Santiago, Canyon, Jesusita, and Station fires for testing to identify any possible characteristics of the ashes and soils from burned areas that may be of concern for their impact on water quality, human health, and endangered species.

The samples were subjected to analysis for bulk chemical composition for 44 elements by inductively coupled plasma mass spectrometry (ICP-MS) after acid digestion and de-ionized water leach tests for $\mathrm{pH}$, alkalinity, conductivity, and anions. Water leach tests generated solutions ranging from $\mathrm{pH}$ 10-12, suggesting that ashes can generate caustic alkalinity in contact with rainwater or body fluids (for example, sweat and fluids in the respiratory tract). Samples from burned residential areas in the 2007 fires had elevated levels for several metals, including: $\mathrm{As}, \mathrm{Pb}, \mathrm{Sb}, \mathrm{Cu}, \mathrm{Zn}$, and $\mathrm{Cr}$. In some cases, the levels found were above the U.S. Environmental Protection Agency (USEPA) preliminary remediation goals (PRG) for soils.

Speciation analyses were conducted on de-ionized water and simulated lung fluid leachates for As(III), As(V), Se(IV), Se(VI), Cr(III), and Cr(VI). All species were determined in the same analytical run using an ion-pairing HPLC-ICP-MS method. For leachates containing high levels of total $\mathrm{Cr}$, the majority of the chromium was present in the hexavalent, $\mathrm{Cr}(\mathrm{VI})$, form. Higher total and hexavalent chromium levels were observed for samples collected from burned residential areas. Arsenic was also generally present in the more oxidized, As(V), form. Selenium (IV) and (VI) were present, but typically at levels below $2 \mathrm{ppb}$ for most samples. Stability studies of leachate solutions under different storage conditions were performed and the suitability of different sample preservation methods for speciation analysis will be discussed.
\end{abstract}

\section{Introduction}

This report contains slides and speaker's notes used for an oral presentation given at the 2010 National Environmental Monitoring Conference (http://www.nemc.us/) held in Washington, D.C., in August 2010.

The slides discuss the growing concern for the high number of acres burned each year in the United States by wildfires and work done by the U.S. Geological Survey in evaluating the potential effects on human and ecosystem health. The U.S. Geological Survey has collected samples of ash and burned soils from a variety of locations in southern California during the 2007 and 2009 fire seasons. Data from samples collected from the Harris, Grass Valley, Jesusita, and Station fires have been analyzed for total metal content. Selected samples with elevated levels of arsenic, selenium, and chromium were analyzed to determine the speciation or chemical form of these elements present. Several tables of results taken from Plumlee and others (2007) are presented in the slides as well as maps depicting locations of the 2007 fires in southern California. The slides also contain preliminary results for the speciation analysis of arsenic, selenium, and chromium by High Performance Liquid 
Chromatography (HPLC) coupled to Inductively Coupled Plasma Mass Spectrometry (ICP-MS) using a modified version of the method discussed by Wolf and others (2007). The slides discuss the modifications made to the method including the use of nitrogen as the reaction gas used in the ICP-MS to remove interferences affecting low-level chromium analyses. The use of nitrogen as a reaction gas allows $\mathrm{As}(\mathrm{III}), \mathrm{As}(\mathrm{V}), \mathrm{Se}(\mathrm{IV}), \mathrm{Se}(\mathrm{VI}), \mathrm{Cr}(\mathrm{III})$, and $\mathrm{Cr}(\mathrm{VI})$ to be determined under the same chromatographic conditions under the same run with Practical Quantitation Limits (PQLs) in the 50 100 ppt range. The Practical Quantitation Limit for this study was defined as the lowest level standard that was recovered within \pm 20 percent of the true value. The slides also discuss issues encountered during speciation analysis including calibration standard purity and stability, sample stability, and vial contamination. The use of an analytical spike on every sample is discussed as a means of assessing overall data quality and determining sample matrix effects on species stability and possible species interconversions. Preliminary results for a study on sample storage conditions are presented which indicate that refrigeration at $1-10^{\circ} \mathrm{C}$ may be the best alternative as analyte losses were seen with room temperature storage $\left(20^{\circ} \mathrm{C}\right)$ and freezing $\left(-21^{\circ} \mathrm{C}\right)$ in the $24-48$ - hour timeframe. Initial testing indicated that the selenium species were not stable under any storage conditions after 48 hours. These studies indicate that the speciation analysis and the sample extraction process should be closely coordinated and the analysis of extracts should begin as soon as possible after extraction.

Preliminary results are presented for several samples from the 2007 and 2009 fires. In addition to the de-ionized water leaching method discussed by Hageman (2007), the samples were also leached using a near-neutral $\mathrm{pH}$ simulated lung fluid (Plumlee and others, 2006) to model potential chemical interactions of inhaled particles with fluids lining the respiratory tract. The preliminary results presented in the slides show that in the de-ionized water leachate, all of the chromium present is in the form of $\mathrm{Cr}(\mathrm{VI})$ and the resulting high $\mathrm{pH}$ tends to stabilize $\mathrm{Cr}(\mathrm{VI})$ from reduction to $\mathrm{Cr}(\mathrm{III})$. Analysis of the simulated lung fluid leachates indicates that the predominant form of chromium present in the nearneutral $\mathrm{pH}$ of lung fluid would be $\mathrm{Cr}(\mathrm{VI})$, which is of concern because of the high possibility of inhalation of the small ash and soil particulates, particularly by fire or restoration crews. The presence of hexavalent chromium, $\mathrm{Cr}(\mathrm{VI})$, in leachates from the fire ash samples is of particular concern because of its known toxicity and carcinogenicity (Agency for Toxic Substances and Disease Registry, 2008).

\section{References Cited}

Agency for Toxic Substances and Disease Registry, 2008, Toxicological profile for chromium - draft for public comment: U.S. Department of Health and Human Services, Public Health Service, September 2008, 610 p., http://www.atsdr.cdc.gov/toxprofiles/tp7.html.

Hageman, P.L., 2007, U.S. Geological Survey field leach test for assessing water reactivity and leaching potential of mine wastes, soils, and other geologic and environmental materials: U.S. Geological Survey Techniques and Methods, book 5, chap. D3, 14 p.

Plumlee, G.S., Martin, D.A., Hoefen, T., Kokaly, R., Hageman, P., Eckberg, A., Meeker, G.P., Adams, M., Anthony, M., and Lamothe, P.J., 2007, Preliminary analytical results for ash and burned soils from the October 2007 southern California Wildfires: U.S. Geological Survey Open-File Report 2007-1407. 
Plumlee, Geoffrey S., Morman, Suzette A., and Ziegler, Thomas L., 2006, The toxicological geochemistry of earth materials: an overview of processes and the interdisciplinary methods used to understand them: Reviews in Mineral Geochemistry, vol. 64, Chapter 2, p 5-57.

Wolf, Ruth E., Morrison, Jean M., and Goldhaber, Martin B., 2007, Simultaneous determination of $\mathrm{Cr}(\mathrm{III})$ and $\mathrm{Cr}(\mathrm{VI})$ using reversed-phased ion-pairing liquid chromatography with dynamic reaction cell inductively coupled plasma mass spectrometry, Journal of Analytical Atomic Spectrometry, vol. 22, p. 1051-1060. 
Slide 1

\section{Speciation of Arsenic, Selenium, and Chromium in Wildfire Impacted Soils and Ashes}

Ruth E. Wolf, Todd M. Hoefen, Philip L. Hageman, Suzette A. Morman, and Geoffrey S. Plumlee

U.S. Geological Survey, MS 964D, Denver Federal Center, Denver, CO 80225

\section{ZUSGS}

Note: This presentation uses two equivalent forms of notation to express the identity of individual species of an element: $\mathrm{Cr}(\mathrm{III})=\mathrm{Cr}^{+3}, \mathrm{Cr}(\mathrm{VI})=\mathrm{Cr}^{+6}$

As (III) $=\mathrm{As}^{+3}, \mathrm{As}(\mathrm{V})=\mathrm{As}^{+3}$

$\mathrm{Se}(\mathrm{IV})=\mathrm{Se}^{+4}, \mathrm{Se}(\mathrm{VI})=\mathrm{Se}^{+6}$ 
Slide 2

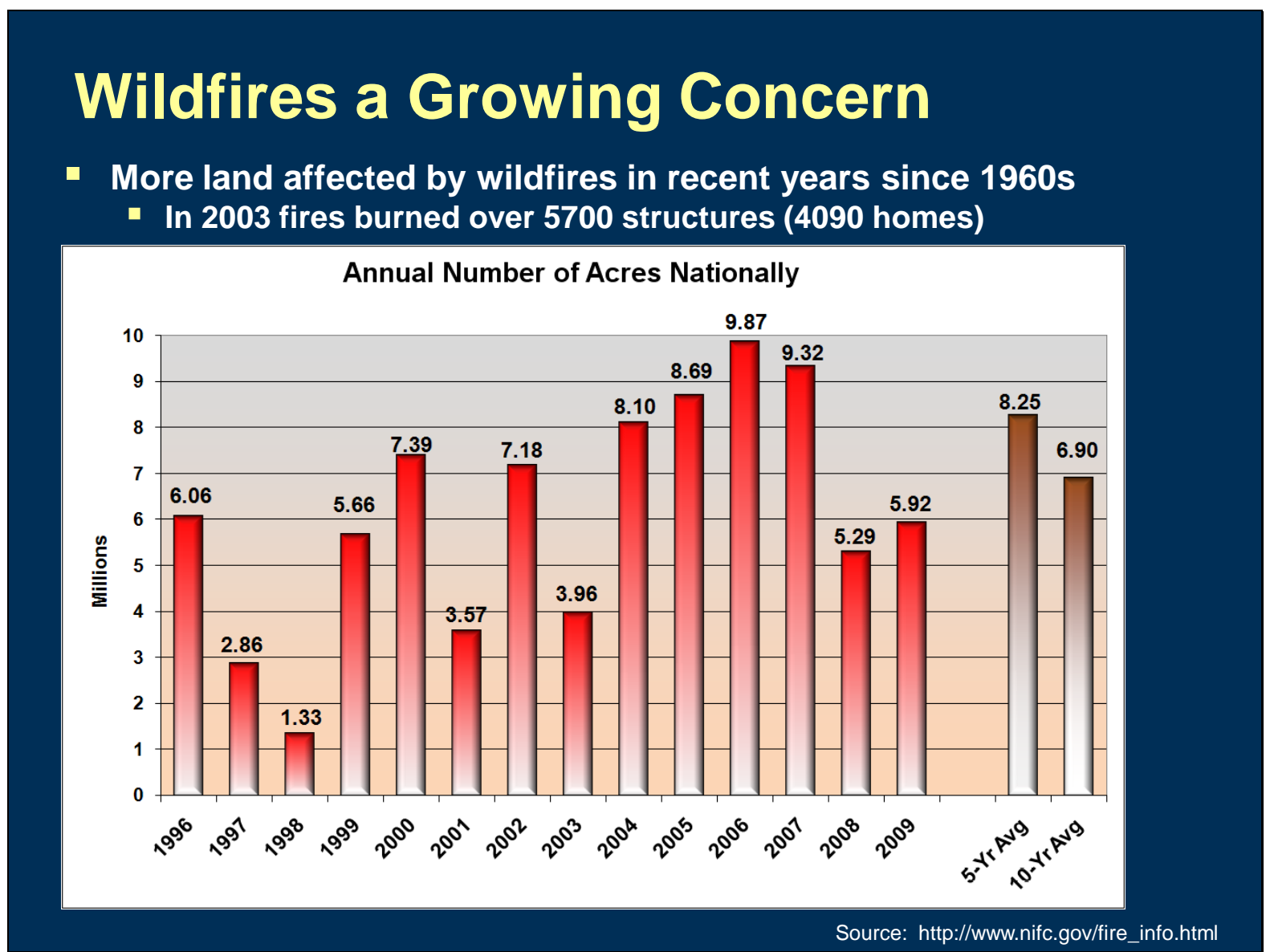

Every year millions of acres of land are affected by wildfires in the United States. The 2006 and 2007 fire seasons were the worst on record since 1996.

Source: http://www.nifc.gov/fire_info.html 


\section{Effects of Fires on Health}

\section{- Immediate}

- Exposure to gases and particulates

- Irritants to eyes and respiratory system

- Complicate chronic heart and lung diseases

- Post-fire and long-term

- Exposure to potentially caustic dusts

- Raise soil and water pH levels

- Exposure to chemicals/metals liberated

- Impact on watersheds and ecosystems

Wildfires can have both immediate and long-term effects on human health. Exposure to the gases and particulates from a fire can cause immediate irritation to the eyes and respiratory system and can cause complications for those with chronic heart and lung diseases. Post-fire and long-term effects can be caused by exposure to potentially caustic ashes and dusts that are skin and eye irritants. They can also impact the environment and ecosystems by raising soil and water pH levels. 


\section{Analysis of Fire Ash/Soil Leachates}

- Large forest fires in California Fall 2007

- Burned many homes and outbuildings

- USGS asked to assess potential risks to human health from residential and nonresidential fire ash

- Expected to vary with particle size and speciation

\section{₹USGS}

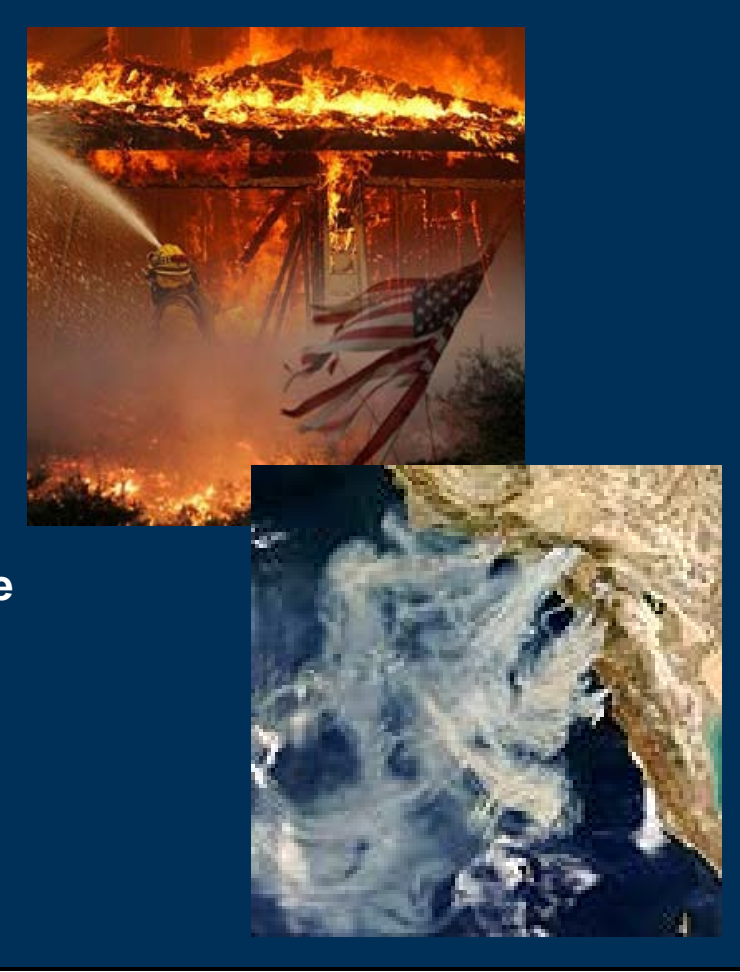

The U.S. Geological Survey was asked by the California Burned Area Emergency Rehabilitation Team (BAER) to assess the potential impact of the large fires in 2007 on human health. The satellite image on the right (from NASA) shows the smoke plumes from these 2007 wildfires as seen from space. Of particular concern were any differences observed between residential and non-residential areas because of the large number of homes and buildings that were destroyed. 
Slide 5

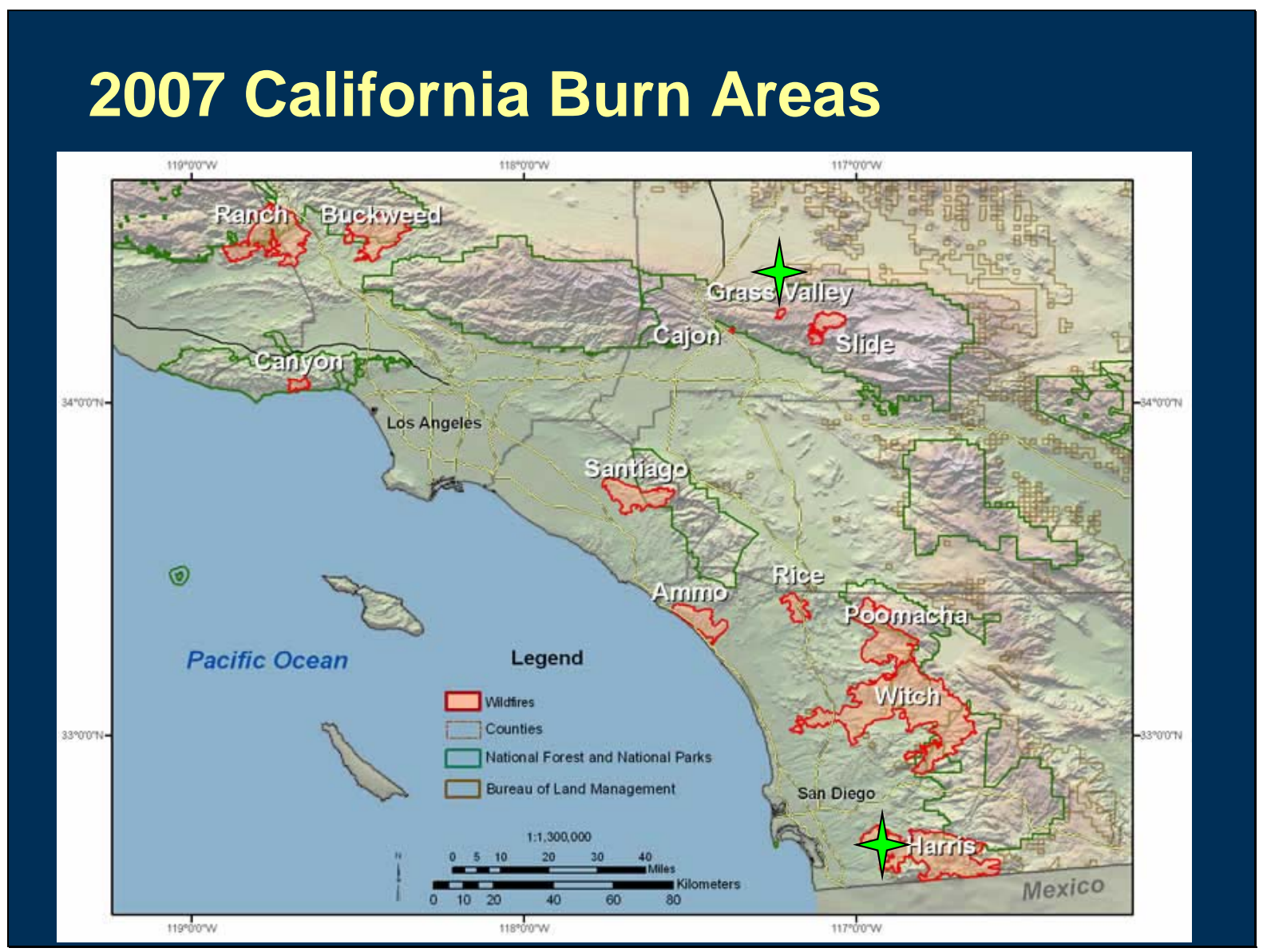

This map shows the major wildfires from the 2007 season in California. The green stars indicate sites studied by USGS that we will discuss in this presentation. More information on the USGS response to the California wildfires can be found at http://www.usgs.gov/hazards/wildfires/ca/. 
Slide 6

\section{Fire Ash Studies - 2007 California Fires}

- Samples from burned wildland and residential areas

- Primary focus on residential ash and soil samples at request of Burned Area Emergency Rehabilitation (BAER) Team

- Report available at: http://pubs.usgs.gov/of/2007/1407/

\section{DUSGS}

News Release

Source: http://pubs.usgs.gov/of/2007/1407/

December 4, 2007

Catherine Puckett
Heidi Koontz

$352-264-3532$
$303-202-4763$

$\frac{\text { cpuckett@usgs.gov }}{\text { hkoontz@usgs.gov }}$

USGS Study Finds Ash from Southern California Fires May Pose Problems to Health and the Environment

Ash from last month's southern California fires may pose problems to health and the environment, according to preliminary results from a U.S. Geological Survey (USGS) study released
to the Multi-Agency State and Federal Task Force.

Samples collected from two residential areas burned by the Grass valley and Harris wildfires indicate that the ash contains caustic alkali materials and can contain somewhat
levels of metals such as arsenic, lead, zinc and copper. Ash from burned wildlands can also contain caustic alkali materials, though at lower levels than the residential ash.

"These findings are consistent with the scientific knowledge about wildfie ash that has led counties in California to issue advisories regarding appropriate precautionary measures
avoid health problems associated with exposure to the ash," said Dr. Geoffrey Plumlee, a USGS lead author of the study.

"The studd results also indicate that rain-water runoff from burned areas may adversely affect ecosystems and the quality of surface drinking water supplies," said Deborah Martin,
USG5 wildfrir ash specialist and study co-author. Additionally, critical habitat for some aquatic species may be affected by spikes in alkalinity as rainwater mixes with ash to form
surface runoff.

The USGS issued a report on the potential impact of wildfire ash on human health and the environment from the work done on the 2007 fires. A wide range of testing was done on the samples, including elemental analysis of the ash materials as well as on leachates from the ash to determine possible impacts. The report is available on the USGS Web site listed above. 


\section{Key Findings}

\section{Preliminary Fire Ash Study}

- Water leach tests generate pH levels $>12$

- Suggest ash can generate caustic alkalinity in contact with rainwater or bodily fluids (e.g., sweat, fluids in respiratory tract)

- Rate of neutralization has not been studied

- Residential ash has elevated levels of metals

- As (140 mg/kg), USEPA PRG (soil) 0.4-0.62 mg/kg

- Pb (344 mg/kg), USEPA PRG 150-400 mg/kg

- $\mathrm{Sb}$ (32 $\mathrm{mg} / \mathrm{kg})$, USEPA PRG $31 \mathrm{mg} / \mathrm{kg}$

- $\mathrm{Cu}(1,370 \mathrm{mg} / \mathrm{kg})$, USEPA PRG 3,100 $\mathrm{mg} / \mathrm{kg}$

- Zn (2,800 mg/kg), USEPA PRG 23,000 mg/kg

- Cr (354 mg/kg)

- USEPA PRG $210 \mathrm{mg} / \mathrm{kg}\left(\mathrm{Cr}^{+6} / \mathrm{Cr}^{+3}=0.17\right), 30 \mathrm{mg} / \mathrm{kg}$ if all $\mathrm{Cr}^{+6}$

- $\mathbf{P R G}=$ Preliminary Remediation Goal

\section{ZUSGS}

Some key findings outlined in the report include the results of de-ionized water leach tests. This quick 5-minute leach in deionized water simulates what happens when the ash comes into contact with rainwater or body fluids such as sweat or in the respiratory tract. Several metals including arsenic $(\mathrm{As})$, lead $(\mathrm{Pb})$, antimony $(\mathrm{Sb})$, and chromium $(\mathrm{Cr})$ were found at levels in the leachate above the USEPA Preliminary Remediation Goals for soils. It is important to note that the PRG for chromium varies, depending on the species of chromium present, and is much lower if $\mathrm{Cr}^{+6}$ or hexavalent chromium is present. 
Slide 8

\section{Extractions Performed}

- De-ionized water leaches - soluble Cr(VI)

- $1 \mathrm{~g}$ in $20 \mathrm{~mL}$ DI water, shaken $\mathbf{5}$ minutes, centrifuge $(3,000$ rpm), $0.45 \mu \mathrm{m}$ filter

- Simulated lung fluid leach

- Estimates effects of particulates $(<38 \mu \mathrm{m})$ taken into lungs and in contact with pulmonary fluids at near neutral $\mathrm{pH}$

- $0.5 \mathrm{~g}$ sample to $20 \mathrm{~mL}$ at $37^{\circ} \mathrm{C}$ for 24 hours

- $150 \mathrm{mM} \mathrm{Na}, 0.2 \mathrm{mM} \mathrm{Ca}, 10 \mathrm{mM} \mathrm{NH}_{4}^{+}, 6 \mathrm{mM}$ glycine, $67 \mathrm{mM}$ formaldehyde, $20 \mathrm{mM}$ methanol, $126 \mathrm{mM}$ chloride, $0.5 \mathrm{mM}$ sulfate, $27 \mathrm{mM}$ hydrogen carbonate, $1.2 \mathrm{mM}$ phosphate, $0.2 \mathrm{mM}$ citrate, adjusted to $\mathrm{pH} 7.4$

\section{¿USGS}

During the USGS studies, two different extractions were performed on the ash samples. The first was a de-ionized (DI) water leach test where $1 \mathrm{~g}$ of ash was added to $20 \mathrm{~mL}$ of de-ionized water and shaken for 5 minutes and filtered. The second was a simulated lung fluid leach which uses a solution similar to lung fluid (the recipe is given above) to estimate the amount of metals leached out when the ash is in contact with the fluids in the respiratory tract and the lungs. This is a 24-hour leach performed at body temperature $\left(37^{\circ} \mathrm{C}\right)$. 
Slide 9

\section{Elemental Content in DI-Leaches}

- Total elemental analysis in $\mathbf{5}$ minute De-ionized (DI) water leach

- Limited information on actual potential for toxicity or impacts on human heath and environment

- Toxicity depends of chemical form of element

- $\mathrm{Cr}(\mathrm{VI}) \gg \mathrm{Cr}(\mathrm{III}), \mathrm{Cr}(\mathrm{VI})$ a known carcinogen (lung)

- $\operatorname{Cr}(\mathrm{VI})$ regulated in several industries with potential for inhalation of $\mathrm{Cr}(\mathrm{VI})$ containing dusts, e.g., welding, refining, plating

- $\mathrm{As}($ III) $>\mathrm{As}(\mathrm{V})$, aquatic species

\begin{tabular}{|l|l|r|r|r|r|}
\hline Sample & \multicolumn{1}{|c|}{ Location Description } & \multicolumn{1}{c|}{$\begin{array}{c}\text { As } \\
(\mu \mathrm{g} / \mathrm{L})\end{array}$} & $\begin{array}{c}\mathrm{Cr} \\
(\mu \mathrm{g} / \mathrm{L})\end{array}$ & $\begin{array}{c}\text { Se } \\
(\mu \mathrm{g} / \mathrm{L})\end{array}$ \\
\hline Harris 06 Ash & Steep hillside & 10.9 & 1 & 1.5 & 7.2 \\
\hline Grass Valley 02 Soil & Hillside & 8.2 & 1 & $<1$ & $<1$ \\
\hline G rass Valley 02 Ash & Hillside & 9.8 & 1 & 1.4 & 3.1 \\
\hline Grass Valley 01 Soil & Modern Homes & 10.9 & 2 & 7.7 & 1.6 \\
\hline Grass Valley 01 Ash & Modern Hom es & 12.7 & 2 & 31.9 & 3.6 \\
\hline Harris 07 Soil & Residential, mobile homes & 10.6 & 219 & 3 & 2.7 \\
\hline Harris 07 Ash & Residential, mobile homes & 12.5 & 13.5 & 32.4 & 6.3 \\
\hline Blank & 6 & $<1$ & $<1$ & $<1$ \\
\hline
\end{tabular}

These data show the total content of 3 potentially toxic elements in the ash from the Harris and Grass Valley fires. In general the soil and ash samples from residential areas had higher levels of arsenic (As) and chromium ( $\mathrm{Cr}$ ) than the non-residential areas.

However, knowing the total concentrations gives us limited information on the potential toxic effects since the toxicity often depends on the chemical form or speciation of the element. For example hexavalent chromium, $\mathrm{Cr}(\mathrm{VI}) \mathrm{or} \mathrm{Cr}^{+6}$ is more toxic than trivalent chromium, $\mathrm{Cr}(\mathrm{III})$ or $\mathrm{Cr}^{+3}$, and is a known lung carcinogen. 


\section{Analytical Method ${ }^{1}$}

- HPLC - reversed phase, ion-pairing

- Column: Brownlee C8

- $3.3 \mathrm{~cm} \times 3 \mathrm{um}$, Si-based ${ }^{2}$

- Column Oven $35^{\circ} \mathrm{C}$

- Mobile Phase:

- $2 \mathrm{mM}$ tetrabutylammonium hydroxide (TBAOH) $+0.5 \mathrm{mM} \mathrm{K}_{2}$ EDTA, $\mathrm{pH}=7.4-7.6$

- EDTA converts $\mathrm{Cr}$ (III) to an anionic EDTA-Cr(III) complex so it can be separated under same

Autosampler $10^{\circ} \mathrm{C}$

- Required for sample stability

- DRC-ICP-MS

- Reaction gas: $\mathrm{N}_{2}$ (removes ${ }^{40} \mathrm{Ar}^{12} \mathrm{C}$

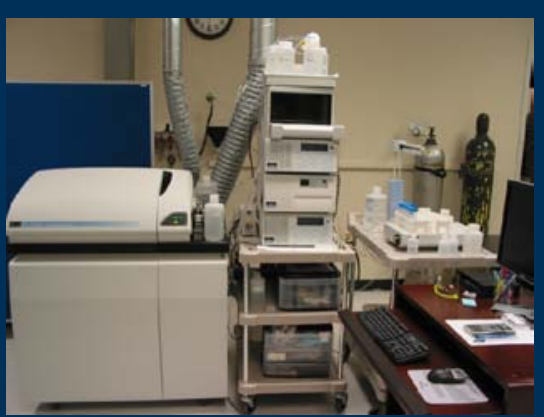

The use of company, trade, and/or product names is for identification purposes only and does not imply endorsement by the United States Government. interference on ${ }^{52} \mathrm{Cr}$ )

- Sample Introduction: Baffled quartz cyclonic spray chamber and Meinhard TQ-30-A3 nebulizer

The method we have been using for speciation at our laboratory is a reversed ion-pairing HPLC separation method followed by ICP-MS detection. We use a small, $3 \mathrm{~cm}$, C8 column with tetrabutylammonium hydroxide as the mobile phase. Elution is isocratic and methanol is added to enhance peak shapes. EDTA is added to the mobile phase and to the samples to complex the $\mathrm{Cr}^{+3}$ cationic species to an anionic $\mathrm{Cr}$ (III)-EDTA complex. The ICP-MS has a dynamic reaction cell that uses nitrogen reaction gas to remove the ${ }^{40} \mathrm{Ar}^{12} \mathrm{C}$ interference at mass 52 that interferes with low-level chromium detection. The method has been modified from the version published in J. Anal. At. Spectrom., 2007, v. 22, p. 1051-1060 to allow determination of arsenic, chromium and selenium species in the same run. 


\section{DRC Reaction Schemes}

- $\mathbf{N}_{2}$ Reaction Gas offers best compromise conditions for all three elements

- If Cr DLs important and [Cl-] is low, $\mathrm{N}_{2}$ or $\mathrm{NH}_{3}$ can be used

- If As DLs important and [Cl-] is high, $\mathrm{O}_{2}$ can be used

\begin{tabular}{|l|c|c|c|c|}
\hline $\begin{array}{c}\text { Signal }{ }^{1} \text { (1 ppb) } \\
\text { Background }\end{array}$ & $\begin{array}{c}\mathrm{N}_{2}=1.0 \\
\mathrm{RPq}=0.50\end{array}$ & $\begin{array}{c}\mathrm{O}_{2}=0.75 \\
\mathrm{RPq}=0.55\end{array}$ & $\begin{array}{c}\mathrm{NH}_{3}=0.65 \\
\mathrm{RPq}=0.60\end{array}$ & $\begin{array}{c}7 \% \mathrm{H}_{2} / \mathrm{He}=1.0 \\
\mathrm{RPq}=0.70\end{array}$ \\
\hline${ }^{52} \mathrm{Cr}$ & 6.4 & 4 & 7 & 1 \\
\hline${ }^{75} \mathrm{As}$ & 51 & 25 & 290 & 200 \\
\hline${ }^{75} \mathrm{As}^{16} \mathrm{O}$ & --- & 340 & --- & --- \\
\hline${ }^{78} \mathrm{Se}$ & 35 & 18 & 9 & 1.5 \\
\hline Normal Mode Bkg ${ }^{52} \mathrm{Cr}$ & $2,377,440$ & $5,507,800$ & $5,155,460$ & $5,725,700$ \\
\hline DRC Mode Bkg ${ }^{52} \mathrm{Cr}$ & $1,480 \mathrm{cps}$ & $6,320 \mathrm{cps}$ & $4,070 \mathrm{cps}$ & $4,653,150$ \\
\hline
\end{tabular}

\section{₹USGS 1 in mobile phase $+5 \% \mathrm{MeOH}$ \\ $2 \sim 90 \%$ conversion of As to AsO (AFT=200V must be optimized)}

For removal of interferences, several reaction gases were examined for the Dynamic Reaction Cell on the ICP-MS. Looking at the signal to background ratios in the mobile phase blank and blank spiked with $1 \mathrm{ppb}$ of arsenic, selenium, and chromium, it was found that the use of $\mathrm{N}_{2}$ as the reaction gas gave the best compromise conditions for all three elements. Other reaction gases can be employed depending on the data quality needs. For example, if the best detection limits are required for chromium, ammonia would be the best choice of reaction gas. 


\section{Detection Capabilities - $\mathbf{N}_{2}$ Gas}

- Calibrated at 1, 2, 5, 10 ppb

- $\operatorname{Ran} 100,200,500$ ppt standards

- Look at accuracy of result at low levels

- As PQL 50 ppt

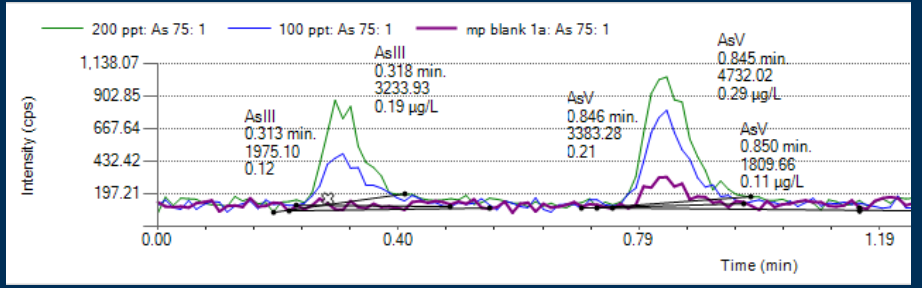

- Se PQL 50 ppt

- Cr PQL 100 ppt CrVI

- Best using $\mathrm{NH}_{3}$ gas
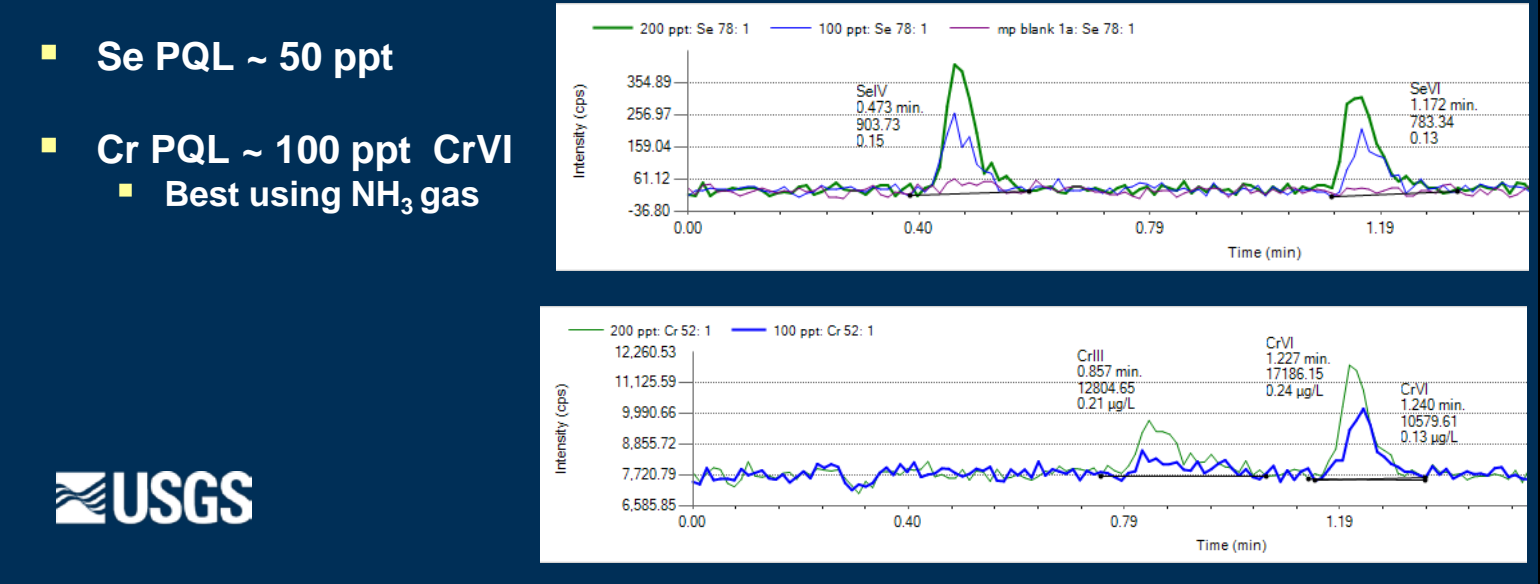

This slide shows low-level standards for each species using nitrogen as the reaction gas. The instrument was calibrated at 1,2 , 5, and $10 \mathrm{ppb}$ and standards at 100, 200, and $500 \mathrm{ppt}$ were analyzed. The Practical Quantitation Limit was established as the spike level where recovery was within 20 percent of the prepared value. So under these conditions using nitrogen as the reaction gas, the As and Se PQLs were 50 ppt and the Cr PQL was 100 ppt (for both species of each element). 


\section{Calibration and Issues}

- $1,000 \mathrm{mg} / \mathrm{L}$ stocks diluted separately to $10 \mathrm{ppb}$ in mobile phase $(\mathrm{pH}=7.6)$

- $\mathrm{As}^{+3}, \mathrm{As}^{+5}, \mathrm{Cr}^{+3}, \mathrm{Cr}^{+6}, \mathrm{Se}^{+4}, \mathrm{Se}^{+6}$ (Source:Spex Certiprep, VHG, Inorganic Ventures)

- Allowed to sit $\sim 30 \mathrm{~min}$ for $\mathrm{Cr}^{+3}$ EDTA complex to form

- Determine retention times

- Evaluate standard stability and contamination issues

- Acps for $\mathrm{As}^{+3} / \mathrm{As}^{+5} \quad 2 \%$

- Acps for $\mathrm{Cr}^{+3} / \mathrm{Cr}^{+6} \quad 1 \%$

- Acps for $\mathrm{Se}^{+4} / \mathrm{Se}^{+6} \quad 4 \%$

- $\mathrm{Se}^{+6}$ contains $\sim 10 \% \mathrm{Se}^{+4}$

- Issue for multicomponent calibrations

\section{ZUSGS}
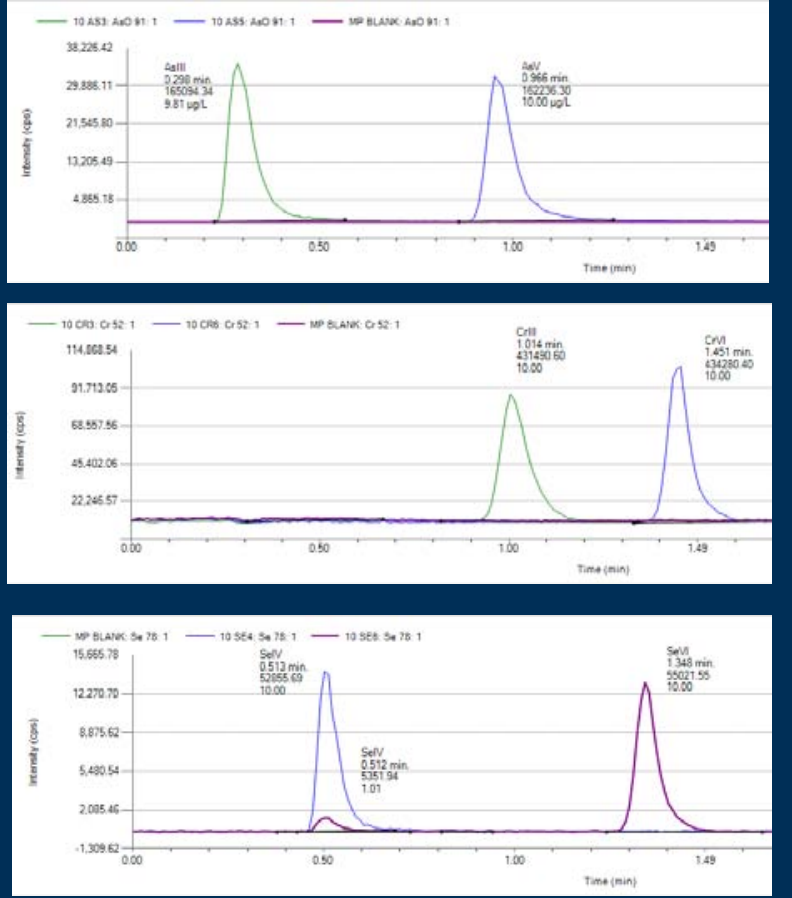

National Scientific PP vials and PKI black/Teflon caps

Calibration was performed with standards prepared from commercially available stock solutions for each species. Three different vendors have been used (Spex, Inorganic Ventures, and VHG Labs). Care should be taken to ensure the standards do not contain significant amounts of the other species. Analysis of each species separately will determine the retention time on the column and allow evaluation of contamination from other species. Note that ideally the areas counts per second for species of the same element should be similar (within 1-2 percent). 


\section{Vial Contamination}

\begin{tabular}{|c|c|c|c|c|c|c|}
\hline Vial and cap type & $\begin{array}{l}\text { As III } \\
\text { (ppb) }\end{array}$ & $\begin{array}{c}\text { As V } \\
\text { (ppb) }\end{array}$ & $\begin{array}{l}\text { Se IV } \\
(p p b)\end{array}$ & $\begin{array}{l}\text { Se Vl } \\
\text { (ppb) }\end{array}$ & $\begin{array}{c}\text { Cr III } \\
(\mathrm{ppb})\end{array}$ & $\begin{array}{r}\text { Cr VI } \\
\text { (ppb) }\end{array}$ \\
\hline Unrinsed Clear Glass w/PKI cap & nd & $9-20$ & nd & nd & nd & nd \\
\hline Rinsed Clear Glass w/PKI cap & nd & $6-10$ & nd & nd & nd & nd \\
\hline Washed Clear Glass w/PKI cap & nd & $0.1-0.4$ & nd & nd & nd & nd \\
\hline Amber Glass w/PKI cap & nd & $0.3-0.7$ & nd & nd & $0.2-0.6$ & nd \\
\hline Rinsed Amber Glass w/PKI cap & nd & 0.1-0.2 & nd & nd & nd & nd \\
\hline Washed Amber Glass w/PKI cap & nd & 0.04-0.07 & nd & nd & nd & nd \\
\hline PKIPP no cap & nd & $0.1-0.3$ & nd & nd & nd & nd \\
\hline N-Sci PP no cap & nd & $0.01-0.03$ & nd & nd & $0.1 ?$ & nd \\
\hline N-Sci PP w/PKI cap & nd & 0.02-0.04 & nd & nd & nd & nd \\
\hline Rinsed N-Sci PP w/PKI cap & nd & 0.03-0.06 & nd & nd & nd & nd \\
\hline Washed N-Sci PP w/PKI cap & nd & $0.01-0.03$ & nd & nd & nd & nd \\
\hline Rinsed N-Sci PP w/TargetDP cap & nd & 0.02-0.06 & nd & nd & nd & nd \\
\hline
\end{tabular}

\section{‡USGS}

Future testing of National Scientific glass vials planned as they are reportedly low in As contamination

When performing speciation analyses everything the samples touch must be checked for possible contamination or residues that might negatively impact the stability of the species being determined. In this table, several types of HPLC vials were checked for contamination. It was found that the clear glass vials used previously for chromium speciation were unsuitable for use when arsenic was also being measured because of high levels of arsenic contamination. In addition, amber glass vials used for arsenic speciation were unsuitable for use when chromium was being determined. Vial blanks should always be tested with every run or change in supplier. Species stability should also be checked with each vial type. Some releasing agents in plastics or washing procedures can cause species instability. 


\section{Quality Control}

- Analytical spikes performed on each sample!

- Allows evaluation of matrix effects on analysis

- Data can be flagged or corrected for spike recovery

- Chromatogram of 25 ppb each As, Se, Cr species

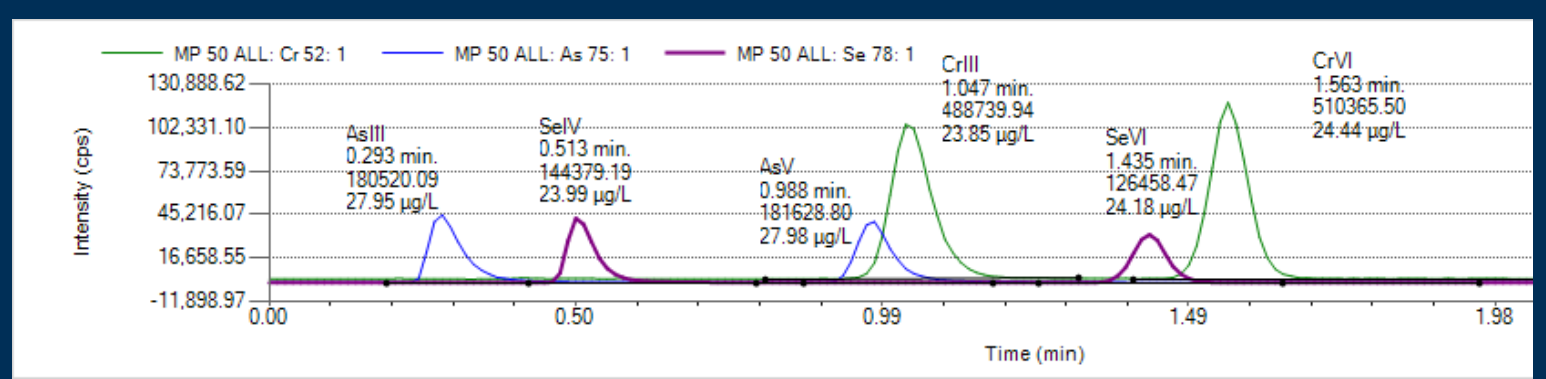

\section{ఇUSGS}

We have found that including an analytical spike on EVERY sample gives us a lot of information about the effects of the sample matrix on the individual species and allows us to assess the quality of the analytical data. Based on the spike results the sample results can either be flagged or corrected for spike recovery. This chromatogram shows a $25 \mathrm{ppb}$ standard with all six species being analyzed: $\mathrm{As}(\mathrm{III}), \mathrm{As}(\mathrm{V}), \mathrm{Se}(\mathrm{IV}), \mathrm{Se}(\mathrm{VI}), \mathrm{Cr}(\mathrm{III})$ and $\mathrm{Cr}(\mathrm{VI})$. Notice the good peak shapes and separation of all species. 


\section{Matrix Effects on Separation}
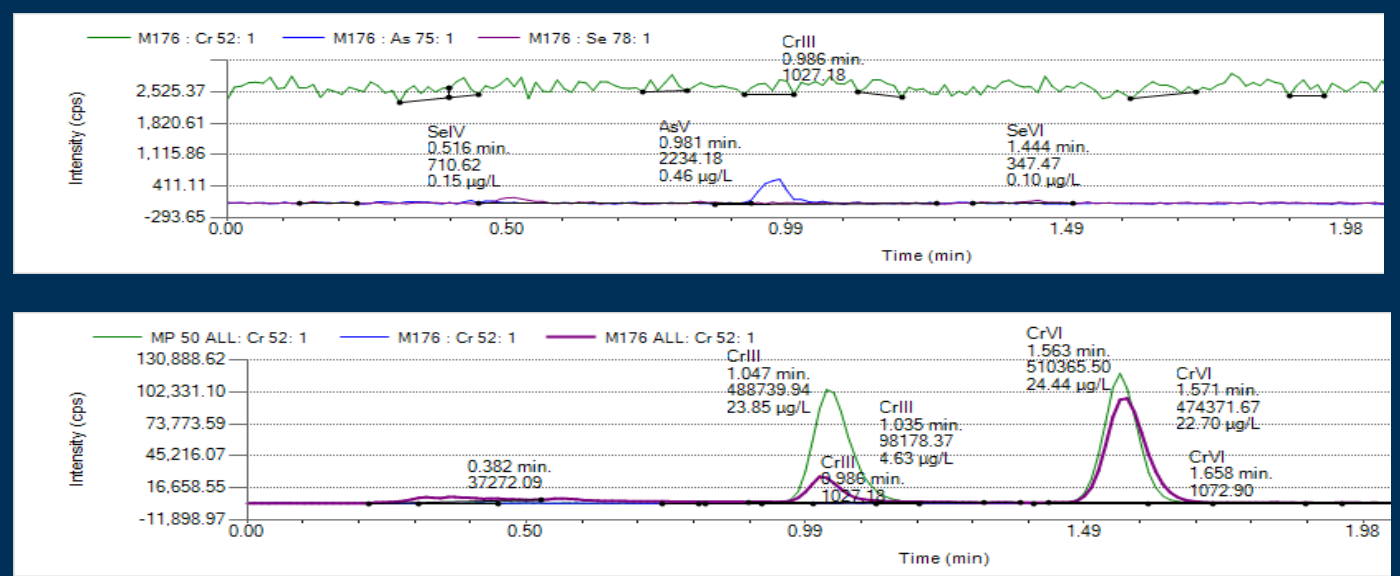

- $\mathrm{M}-\mathbf{1 7 6}$ water reduces some $\mathrm{Cr}(\mathrm{VI})$ to $\mathrm{Cr}(\mathrm{III})$

- http://bqs.usgs.gov/srs/

- $\mathrm{Cr}$ (III)-EDTA peak is smaller than expected, another Cr peak at early RT...

\section{₹USGS}

These two chromatograms are from a USGS reference water sample M-176 (available at http://bqs.usgs.gov/srs/) which has routine levels of major cations and anions and should not contain As, Se, or Cr in significant levels. The upper chromatogram shows M-176 alone has a small amount, $0.5 \mathrm{ppb}$, of $\mathrm{As}(\mathrm{V})$ present. However when this sample is spiked at $25 \mathrm{ppb}$ (the same level as the previous slide), we see that the $\mathrm{Cr}(\mathrm{VI})$ is somewhat smaller than expected (maroon line) compared to the standard (green line). In addition the $\mathrm{Cr}(\mathrm{III})$ is significantly smaller and there is another broad chromium peak appearing earlier in the chromatogram. This could indicate that the levels of major cations are competing for the EDTA in the Cr(III)-EDTA complex and causing it to fall apart. For this sample, the chromium speciation values would be unreliable based on the spike results. 


\section{Matrix Effects on Separation}

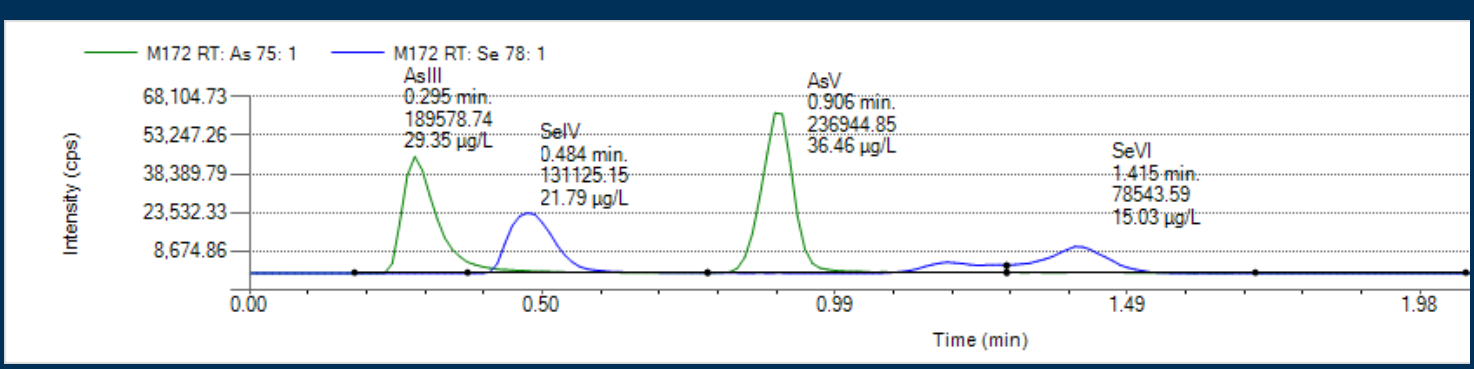

- M-172 water matrix spiked with all species

- Shows As(III) to As(V) conversion

- Shows Se(VI) peak is splitting

\section{₹USGS}

The analytical spike on another USGS reference water sample, M-172, shows that the As(III) is possibly being converted to $\mathrm{As}(\mathrm{V})$ and there may be some matrix-induced signal enhancement since both peaks read significantly higher than the expected $25 \mathrm{ppb}$. Note: an internal standard is not being used to correct for signal drift. Also the Se(Vl) peak appears to be spread out and separating into $2 \mathrm{Se}(\mathrm{VI})$ peaks. In this case the peak detection parameters might need to be adjusted to integrate the both peaks from $\mathrm{Se}(\mathrm{VI})$ - if we are sure they are both from $\mathrm{Se}(\mathrm{VI})$. For this sample, the arsenic and selenium data should be flagged as possibly containing significant error. In general, the analytical spike values on all the sample results we will discuss today were within 20 percent of the expected value. 


\section{Stability}

- All species stable in mobile phase (pH 7.6) for $\sim 24$ hours at $20^{\circ} \mathrm{C}$

- Can extend to $\mathbf{4 8}$ hours at 1$10{ }^{\circ} \mathrm{C}$

- Se not stable after $\mathbf{4 8}$ hours

- Freezing appears to be detrimental for all species

- Not flash frozen

- 1-2 $\mathrm{mL}$ total volume

- Stability varies with matrix another reason for spikes on each sample

\section{₹USGS}

Cr Stability at $20 \mathrm{C}$

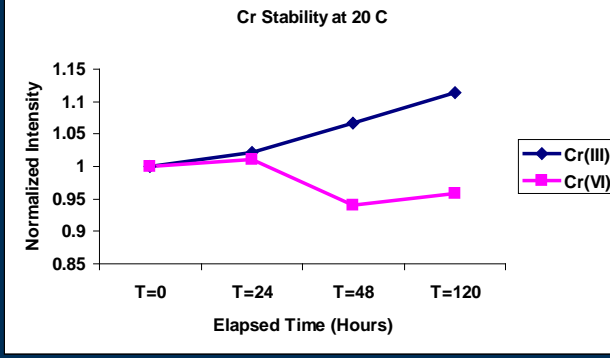

Cr Stability at $1 \mathrm{C}$

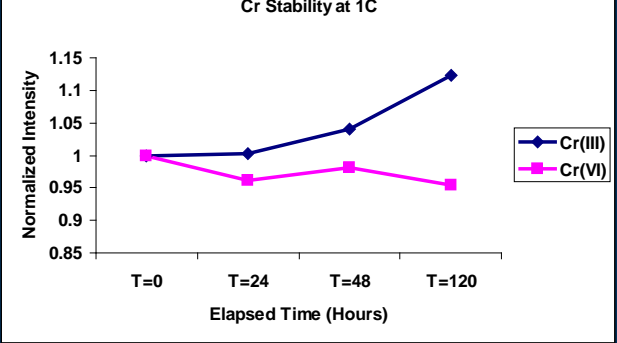

Cr Stability at $-20 \mathrm{C}$

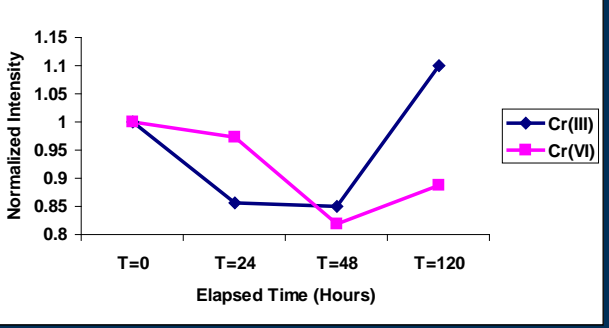

For speciation, stability testing is critically important. The sample collection and storage conditions (for example, light vs. dark, temperature, preservative, sample matrix, etc.) can drastically affect the stability of the species you are trying to measure. Our tests showed that our standards were stable in the mobile phase for only 24 hours at room temperature. If refrigerating or using a Peltier-cooled autosampler, stability could be extended to 48 hours by keeping the standards at $1-10^{\circ} \mathrm{C}$. Our testing showed that after 48 hours both selenium species were not stable. In addition, freezing in a normal freezer (as compared to liquid nitrogen flash freezing) appeared to be detrimental for ALL species. The stability will also vary with the sample matrix and the presence of known oxidizing or reducing agents in the sample. All the samples tested were kept in the dark or shielded from the light unless being aliquoted, this is extremely important for As as it has been documented sunlight can oxidize $\mathrm{As}^{+3}$ to $\mathrm{As}^{+5}$ quite rapidly. 


\section{Stability Must Be Checked}

- Matrix and/or temperature can influence!

- 48 hours after spiking

- All analyses done same day as leaching
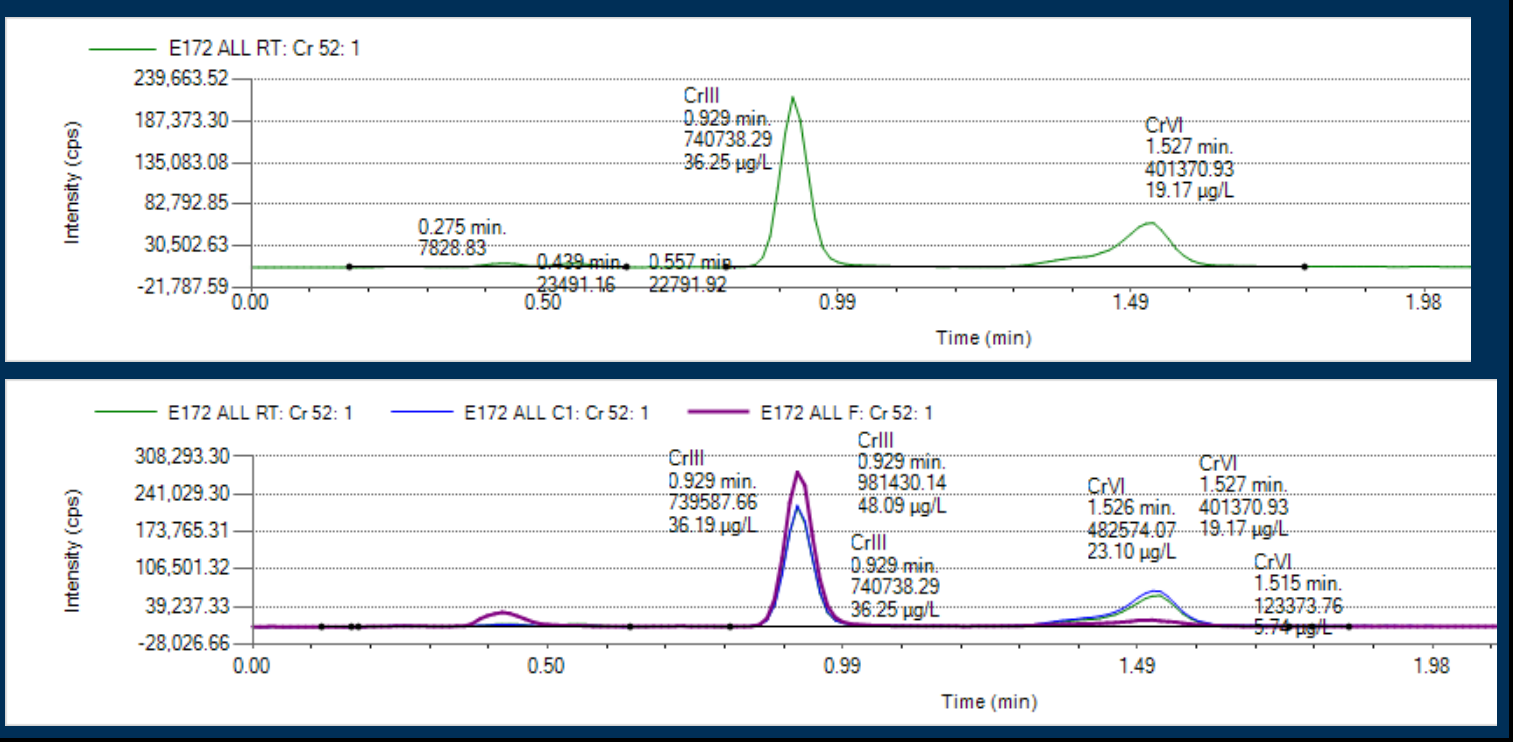

Since the sample matrix can drastically influence species stability we found that performing analytical spikes on a separate aliquot of each sample as they are being diluted for analysis is critical in assessing matrix effects on the results. The top chromatogram shows that in the $\mathrm{M}-172$ reference water, $\mathrm{Cr}(\mathrm{VI})$ is significantly converted to $\mathrm{Cr}(\mathrm{III})$ after 48 hours and that freezing the sample actually increases the amount of $\mathrm{Cr}(\mathrm{VI})$ reduced. Subsequently, all of our speciation analyses are coordinated to begin immediately after samples are collected or leached to minimize storage effects on the sample results. Storage prior to analysis is at $4-10^{\circ} \mathrm{C}$. 


\section{CA Fires - Total Cr vs. Cr(VI)}

- More $\mathrm{Cr}$ is leached out in lung fluid leach

- Ash samples liberate much higher Cr values

- Significant portion of it is $\mathrm{Cr}(\mathrm{VI})$

- OSHA PEL (8 Hr) $\mathrm{Cr}(\mathrm{VI})=5 \mu \mathrm{g} / \mathrm{m}^{3}$

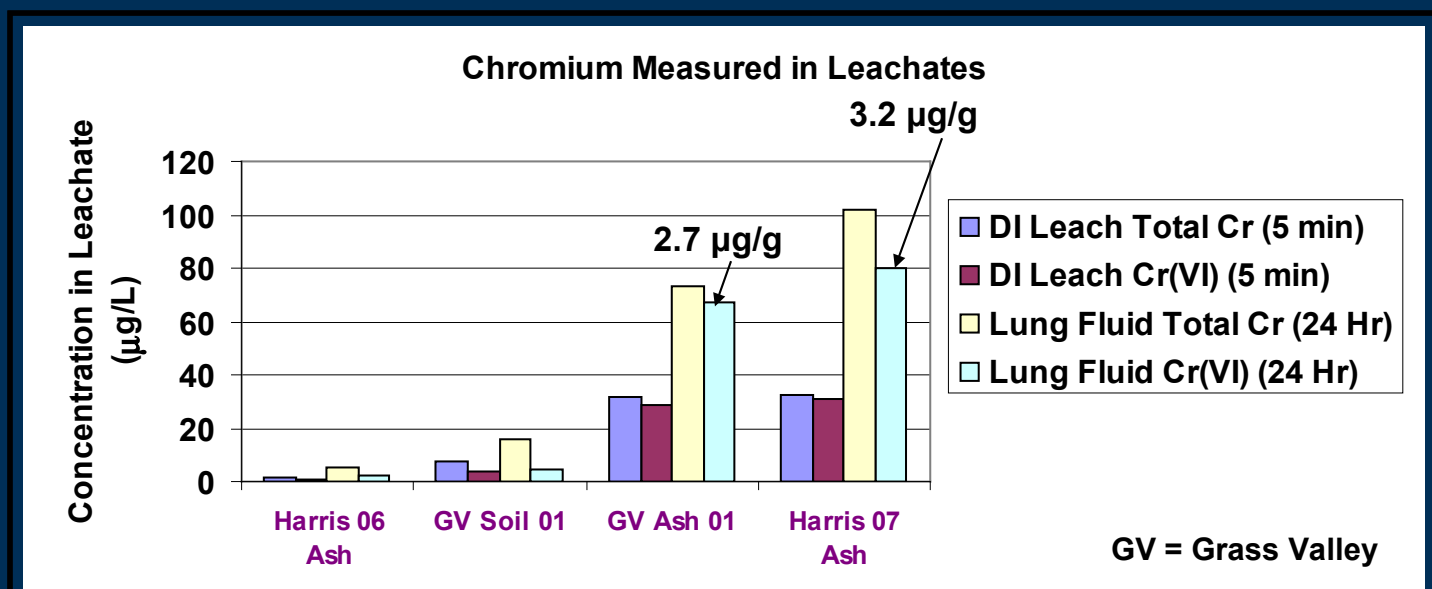

So back to our results. The DI and simulated lung fluid leaches performed on ash and soil samples with elevated arsenic and chromium levels show that as the ash samples from residential areas (GV Ash 01 and Harris 07 Ash) contact de-ionized water and the simulated lung fluid, chromium is released and the predominant form of chromium present is hexavalent chromium, $\mathrm{Cr}(\mathrm{VI})$. This is not surprising given the oxidizing conditions in a fire and the high $\mathrm{pH}$ values associated with the ash samples. Moreover, the lung fluid leach resulted in significantly more chromium being extracted from the ash and again, the predominant form of this is hexavalent chromium. Air monitoring data are needed in order to compare the concentrations of $\mathrm{Cr}(\mathrm{VI})$ found in $\mu \mathrm{g} / \mathrm{g}$ ash to the OSHA PEL of $5 \mu \mathrm{g} / \mathrm{m}^{3}$. 


\section{CA Fires - Total As vs. As(V)}

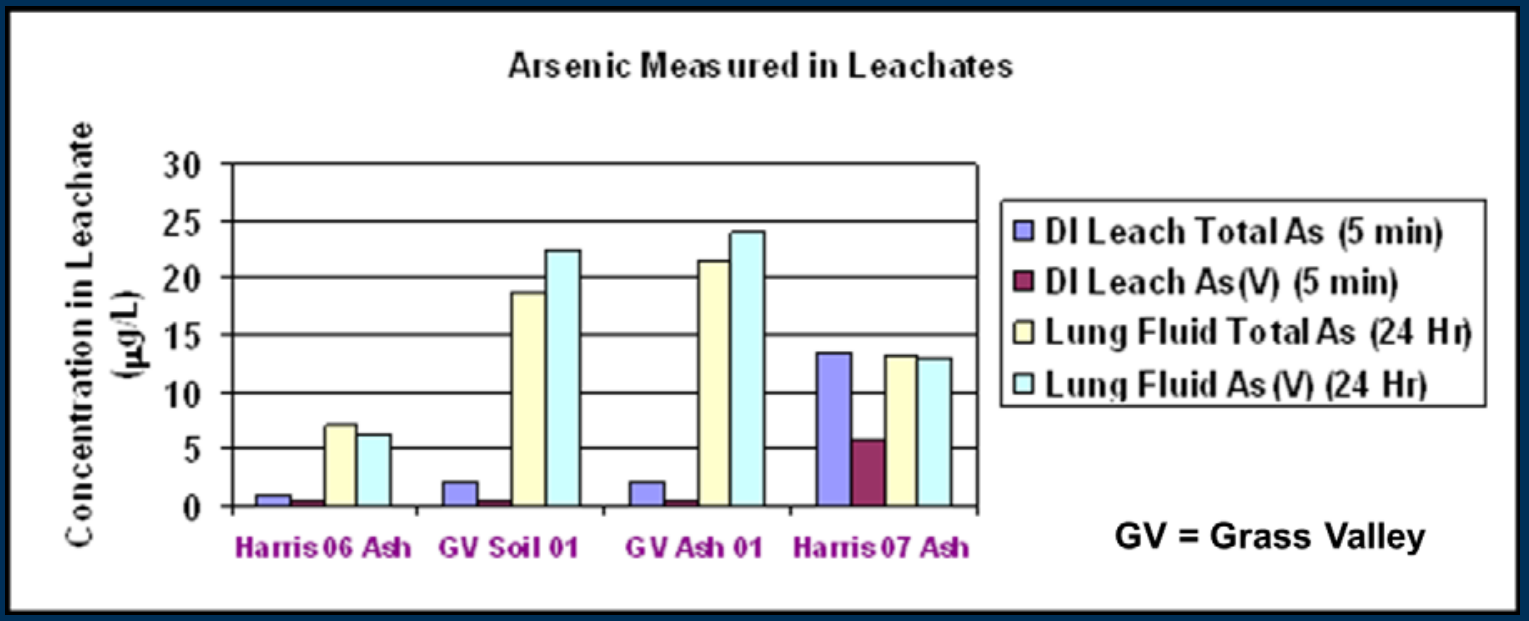

- Se $<2$ ppb (all forms)

\section{ZUSGS}

For arsenic, again we see some amount of arsenic is extracted in the DI water leach and some of it is present as As(V). However, in the simulated lung fluid leachates, significantly more arsenic is extracted and the predominant form is As(V). For selenium, for all samples Se in all forms was less than $2 \mathrm{ppb}$ in all extracts. 


\section{Jesusita Fire - Arsenic}

- DI Water Leach

- Most As present in oxidized As(V) form

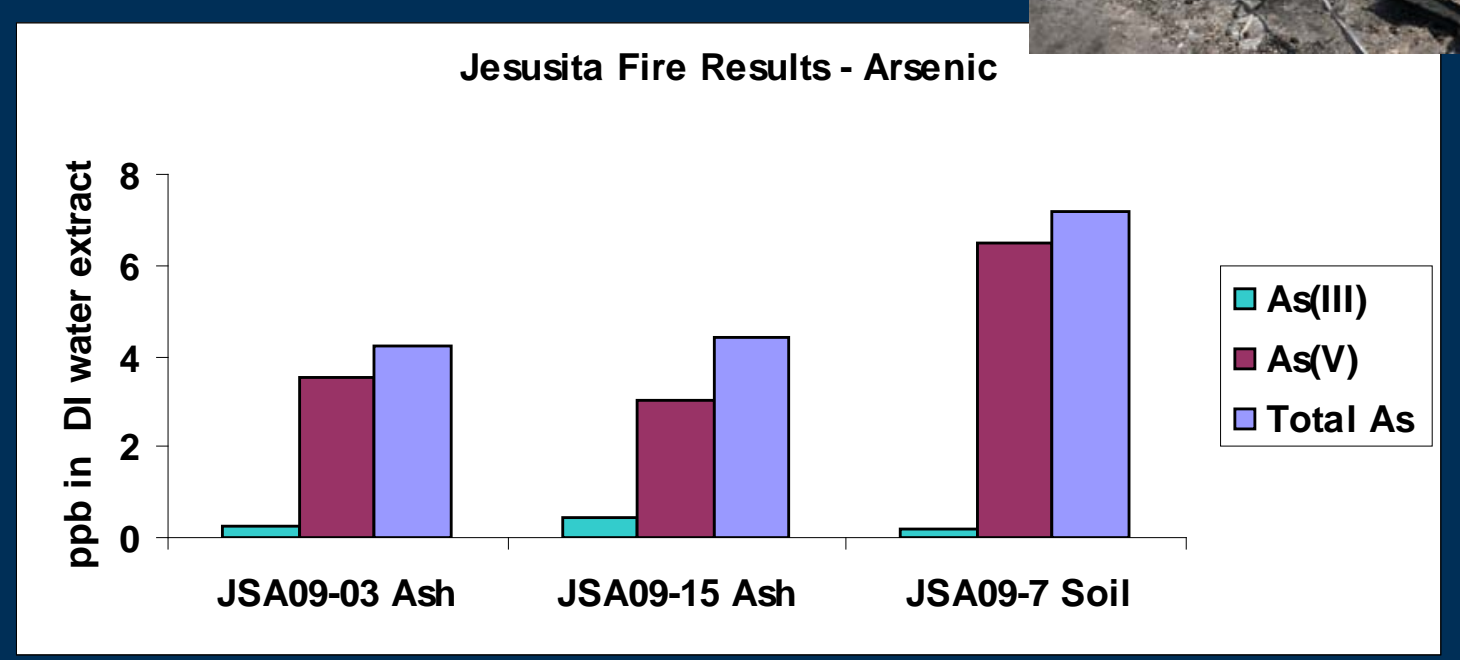

Similar leaching experiments were carried out with soil and ash samples from the 2009 Jesusita fire. In the DI water leach, low levels of arsenic were extracted and the predominant form was again $\mathrm{As}(\mathrm{V})$. The sum of the measure $\mathrm{As}(\mathrm{III})$ and $\mathrm{As}(\mathrm{V})$ values matches well with the total arsenic values measured using traditional ICP-MS analysis. 


\section{Jesusita Fire - Chromium}

\section{- DI Water Leach}

- Most Cr present was in more toxic $\operatorname{Cr}(\mathrm{V})$ form

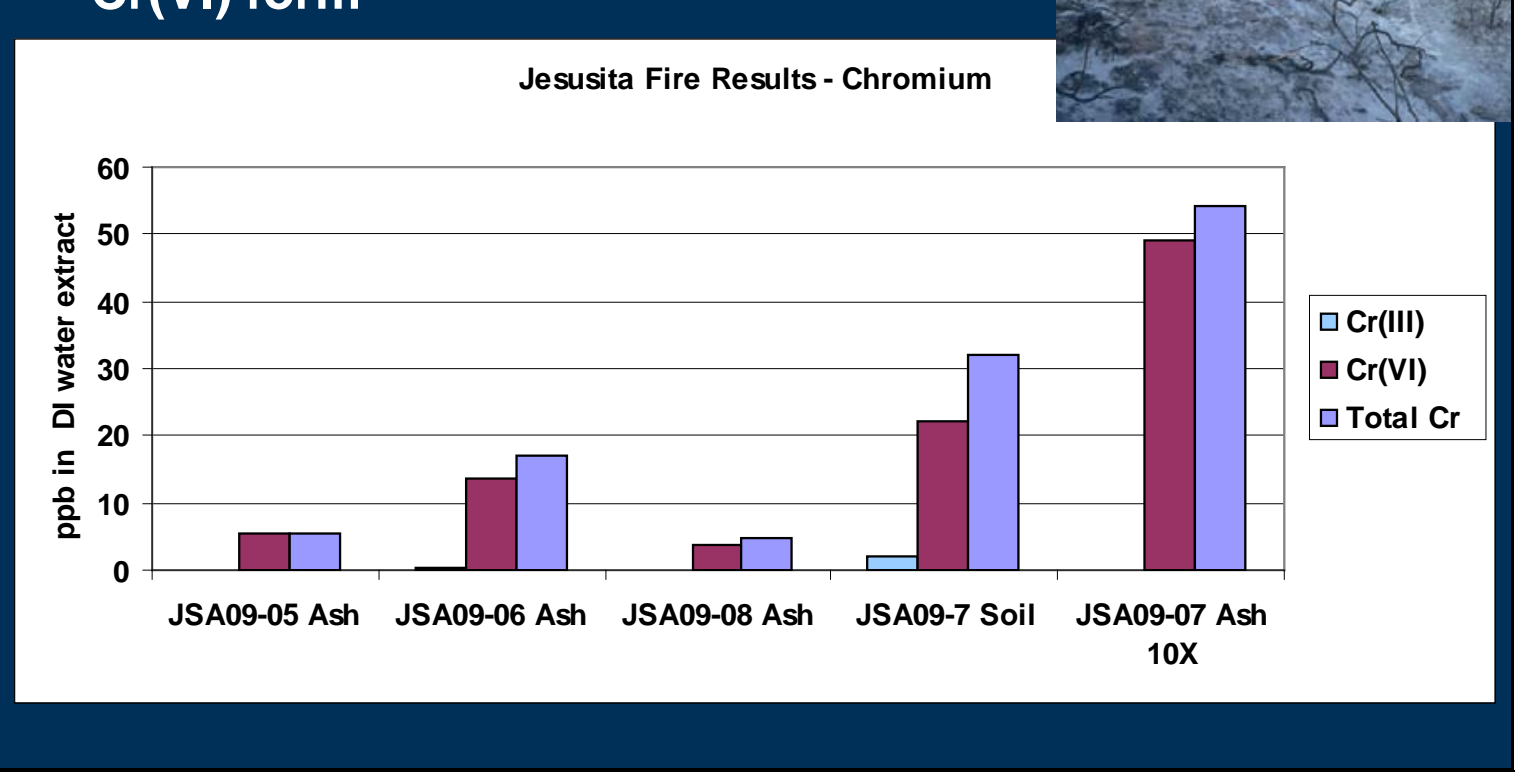

In the case of chromium from the Jesusita fire, a significant level of chromium was leached out of some samples and again the predominant form was $\mathrm{Cr}(\mathrm{VI})$. One residential sample (JSA09-07) had 10 times the amount of the rest of the samples. It should be noted that in California the total chromium limit in drinking water is $50 \mu \mathrm{g} / \mathrm{L}$ while the Federal limit remains at $100 \mu \mathrm{g} / \mathrm{L}$. In August 2009, the California Office of Environmental Health Hazard Assessment issued a draft Public Health Goal (PHG) for $\mathrm{Cr}(\mathrm{VI})$ of $0.06 \mu \mathrm{g} / \mathrm{L}$. The California Department of Health Services is currently working on a Maximum Contaminant Limit for $\mathrm{Cr}(\mathrm{VI})$ based on this PHG. See http://www.cdph.ca.gov/certlic/drinkingwater/Pages/Chromium6.aspx for current status and information. 


\section{Station Fire - Chromium}

- Chromium in burned residential areas high and predominately $\mathrm{Cr}(\mathrm{VI})$ in DI water leach

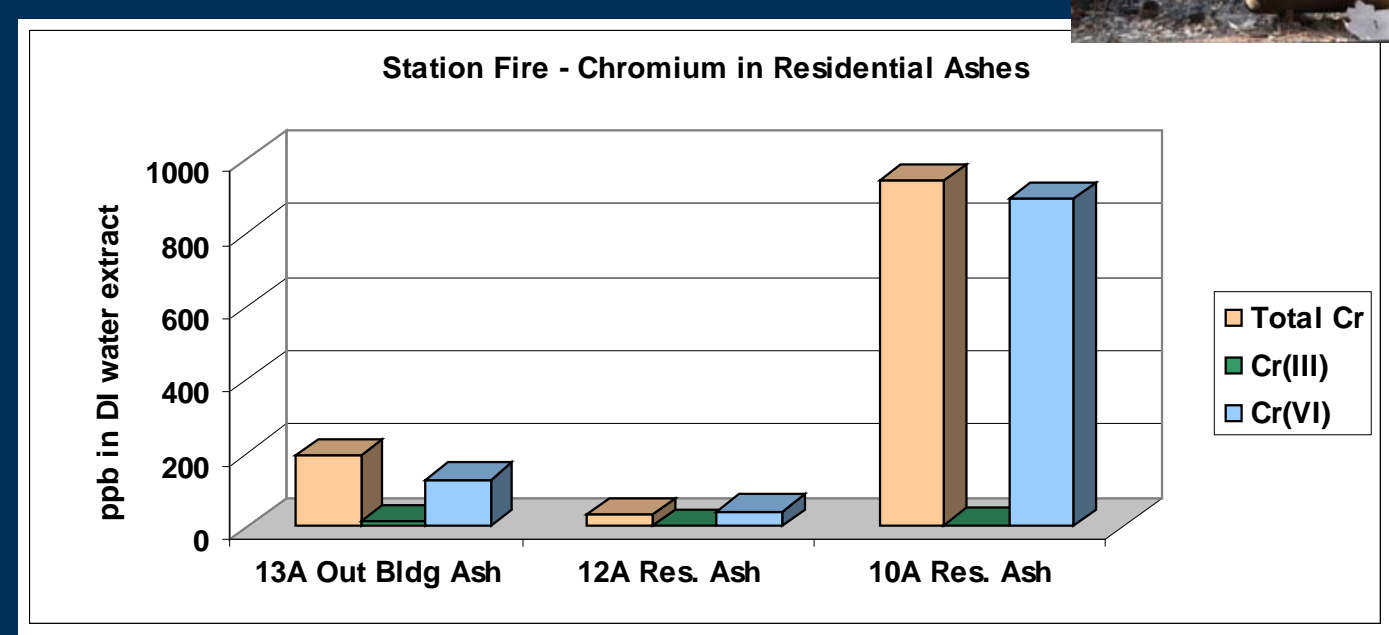

A few samples from the 2009 Station Fire showed significant levels of total chromium (150-850 ppb) present in the 5 minute DI water leach. Again, our speciation analysis indicates that the predominant form of chromium present is hexavalent chromium. 


\section{Station Fire - Chromium}

- DI Water Leach

- Lower Cr values than residential samples

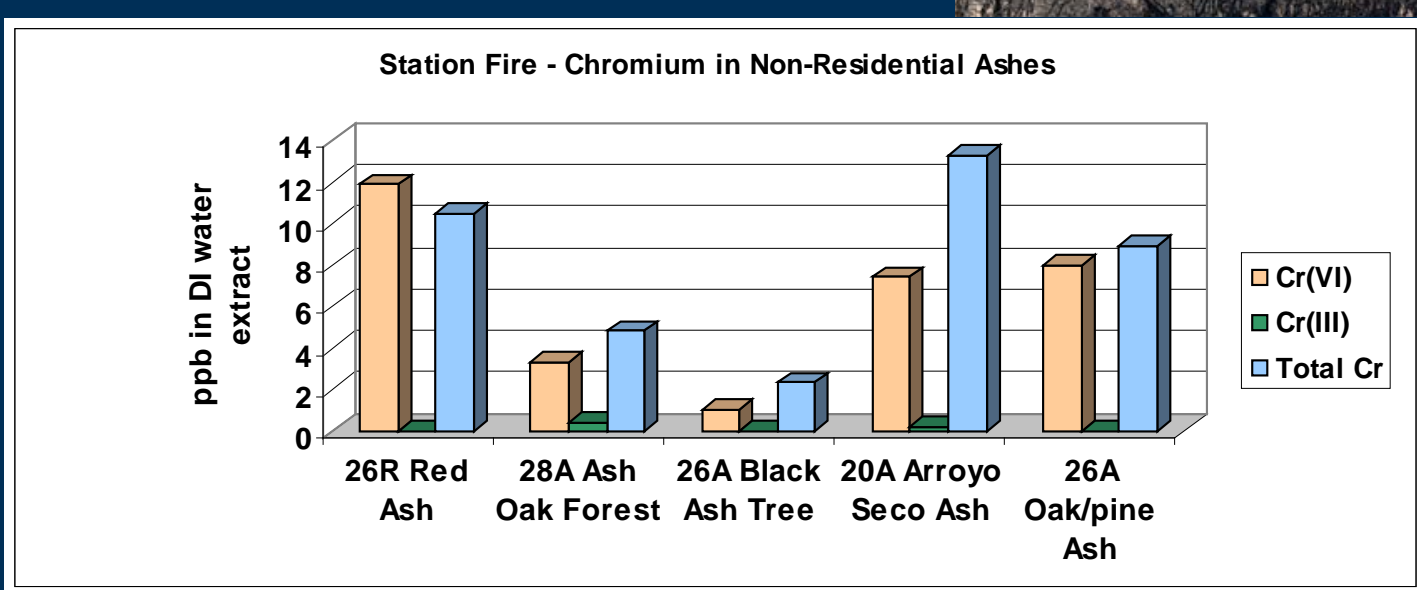

In samples from nonresidential areas in the Station Fire the total levels of chromium extracted in the DI water leach were significantly less than seen from the residential samples. Since chromium is used in many textiles, wood preservatives, and other household items, finding higher levels of chromium in residential areas is not surprising. Again, the speciation analysis indicates the predominant form of chromium present in the leachates is hexavalent chromium. 


\section{Conclusions}

- Analytical method can be used to determine inorganic forms of As, Se, and $\mathrm{Cr}$ in a variety of matrices

- Soils and ashes from residential areas have higher Cr(VI) levels than wildland areas

- Predominant form of $\mathrm{Cr}$ found in fire-impacted soil and ash samples is $\mathrm{Cr}(\mathrm{VI})$

- Alkaline pH resulting from contact of ash with water and water-based fluids may have a stabilizing effect on $\operatorname{Cr}(\mathrm{VI})$

- Potential human health impact from high pH and for exposure to $\mathrm{Cr}(\mathrm{VI})$-containing ash and soils by firstresponders and clean-up crews

- Particularly for inhaled ash particles that are high in $\mathrm{Cr}$

- Air monitoring tests for $\mathrm{Cr}(\mathrm{VI})$ suggested during fire clean-up/recovery operations to assess health effects

₹USGS

In summary, our speciation method can determine the inorganic forms of As, Se, and Cr in a variety of matrices.

Leach studies on ash and soil from fire-impacted areas indicates that the predominant form of chromium found is the hexavalent form. This is of importance to first responders, clean-up crews, and homeowners who may have physical contact or breathe in these ash and soil particles. Since hexavalent chromium is a known lung carcinogen, we need more studies and air-monitoring testing in order to fully evaluate the potential effects on human health from exposure to these fire-impacted ashes and soils. 